\title{
Do Firms Who Give Globally Secure Future Financial Performance? An Investigation of US Service Firms
}

\author{
Cowan Adrian ${ }^{1}$, Padmanabhan Prasad $^{2} \&$ Huang Chia-Hsing ${ }^{3}$ \\ ${ }^{1}$ Analytic Focus, LLC, San Antonio, Texas, USA \\ ${ }^{2}$ Greehey School of Business, St. Mary's University, San Antonio, Texas, USA \\ ${ }^{3}$ SolBridge International School of Business, Daejeon, South Korea \\ Correspondence: Prasad Padmanabhan, Greehey School of Business, St. Mary's University, One Camino Santa \\ Maria, San Antonio, Texas, 78228, USA. Tel: 1-210-431-2034. E-mail: Ppadmanabhan1@stmarytx.edu
}

Received: May 8, 2015

Accepted: June 4, 2015

Online Published: July 22, 2015

doi:10.5539/ijbm.v10n8p29

URL: http://dx.doi.org/10.5539/ijbm.v10n8p29

\begin{abstract}
To date, there is no conclusive evidence on whether current domestic giving impacts future financial performance. In addition, no one seems to have investigated whether foreign charitable contributions or global charitable contributions made by US service firms impact subsequent financial performance. In this paper, using the Kinder, Lydenberg, Domini data base (where only the incidence of domestic/foreign giving are recorded) and logit regression methodology, we show that there is a strong positive correlation between the incidence of current domestic giving by US service firms and future financial performance for the 2004-2014 period. However, the incidence of current foreign giving (or foreign and domestic giving) does not seem to result in future financial benefits for US service firms. Specifically, after controlling for the variables traditionally associated with giving (foreign and/or domestic), the incidence of current giving is only strongly positively associated with future financial performance for the domestic giving sample.
\end{abstract}

Keywords: foreign giving, us service firms, future financial performance

\section{Introduction}

\subsection{Rationale for the Study}

Following revenue growth in international markets, international charitable giving by U.S. firms increased from $5.3 \%$ in 2005 to $14 \%$ of total giving in 2011 . The service sector has been the largest and fastest growing sector of the U.S. economy and accounted for about 79.6\% of U.S. GDP in 2011 (United States CIA, 2013). Given the recent growth in the service sector, the paucity of studies that examine the giving phenomenon in relation to this sector is surprising. According to the Committee Encouraging Corporate Philanthropy (CECP), there are significant differences between the service sector and the manufacturing sector insofar as it pertains to the practice of international corporate philanthropy. Annual survey results conducted in 2011 by Corporate Giving Standards (CGS), indicate that whereas the manufacturing sector accounted for around $22 \%$ of overall giving dollars, the service sector only accounted for $7 \%$. In addition, both sectors differ in terms of the geographic patterns of international giving. Clearly, there are significant differences in giving patterns between these sectors. The corporate philanthropy/financial performance links have been explored in the literature (e.g., Seifert et al., 2004; Brown et al., 2006; Wang et al., 2008; Margolis et al., 2007). Despite mixed results, the meta-analysis examination of 167 studies by Margolis et al. (2007) documents a positive relationship between corporate social responsibility and corporate profitability.

To date, studies of international aspects of corporate social responsibility are primarily limited to Corporate Social Responsibility (CSR) in the broad sense and not specifically limited to philanthropy. Strike et al. (2006) investigate whether international diversification impacts corporate social responsibility and/or irresponsibility. In addition, many international philanthropy based studies tend to focus exclusively on the determinants of giving, as opposed to exploring the international giving/future firm performance links, but only for manufacturing firms (Muller \& Whiteman, 2009; Cowan et al., 2013). Few studies examine the stated links for U.S. service firms. Given the significant differences in giving patterns for manufacturing vs. service firms, understanding the international giving/corporate profits link can provide strategic benefits for service firms. Waddock and Smith 
(2000) argue that global philanthropy may provide competitive advantages for firms. If global philanthropy should positively impact future financial performance for firms in the service industry then global philanthropy expenditures may be better viewed as a capital/marketing expenditure. Service companies could possibly use evidence of a positive linkage to optimize future financial performance by giving globally. Hence, this paper examines the relationship of global philanthropy with the future financial performance of firms in the U.S. service sector.

Section 2 provides details related to the available literature on the theoretical and empirical links between corporate charitable contributions and future firm performance. Section 3 is a brief description of the data bases used (US M\&A data base and the Kinder, Lydenberg, Domini (KLD) Socrates data base (see Cowan et al., 2013, for a description)), and outlines the specific dependent and independent variables utilized in this study. Sample characteristics and a brief description of the logit regression methodology used are also presented in Section 3. Empirical results presented in Section 4 are followed by policy implications and concluding comments in Section 5.

\subsection{Literature Review}

This paper empirically examines the relationship between service industry philanthropic giving and corporate future financial performance. Philanthropy represents an important component of corporate strategy on social responsibility as it represents an action that can be identified and measured (Maron, 2006). Some argue that corporate philanthropic decisions are most frequently determined by board members (Brammer \& Millington, 2003) and that philanthropy has been shown to have an impact on the corporate image as it is seen by all stakeholders (Porter \& Kramer, 2002). If companies detect a significant philanthropic giving/ future financial performance statistical link, then firms could pursue a profit maximization goal through strategic foreign giving. Does giving globally also provide performance related benefits to service firms?

Value enhancing theory and agency theory provide the main conceptual foundations for empirical research. Value enhancing theories indicate a positive link between corporate giving to charity and financial performance, but agency cost theory posits a negative relationship between the two variables. The value enhancing theories include reputation theory, value maximization theory, legitimacy theory, and strategic philanthropy. Collectively, these theories show that corporate charitable giving maximizes value (both financial and non-financial). However, the motivations for charitable giving differ between the theories. Brammer and Millington (2005) define reputation theory as the collective opinion of an organization held by its stakeholders, and that corporate giving positively influences firm reputation via its link to future firm level profits (Wilson, 1985). Giving to charity can increase customer loyalty and increase revenue (Roberts \& Dowling, 2002), reduce customer price sensitivity (Navarro, 1988), or reduce wages and increase labor productivity (Turban \& Greening, 1996). Value maximization theory imputes that financial benefits accrue from friendlier governmental treatment (and a better reputation), resulting in value maximization (Brown et al., 2006). Next, legitimacy theory proponents argue that organizational existence can depend on legitimacy (Shocker \& Sethi, 1974), and corporate giving can serve as a legitimacy-seeking strategy (Dowling \& Pfeffer, 1975; Chen et al., 2008). Generating a positive corporate image can combat poor corporate social behavior elsewhere. Finally, strategic philanthropy suggests that giving to charity improves a firm's strategic position and increases profit by enhancing a company's competitive advantages. Firms can consider their philanthropic activities (Saiia et al., 2003) as part of corporate strategy. Indeed, corporate charitable spending can be included in the firm's total spending portfolio (Sanchez, 2000).

In contrast, agency cost theory proponents argue for a negative philanthropic giving/corporate financial performance link by suggesting that corporate philanthropic giving is an agency cost to the firm. Following Jenson and Meckling (1976), corporate giving by agents (managers), perhaps driven by their personal image and reputation enhancement (Jensen \& Meckling, 1976; Fama, 1980; Fama \& Jensen, 1983), can serve as an agency cost to owners. Diversion of corporate resources by managers to promote their interests will harm the interests of owners. Although these strategies can be controlled by heavy monitoring of managers (Jenson, 1986), such actions reduce firm value because it necessitates the divergence of funds from profitable projects to institute increased monitoring activities. Using different measures of financial performance, Margolis et al. (2007) find that the relationship between corporate philanthropy and financial performance is mixed. In contrast, Frombrun and Shanley (1990) find a positive relationship between philanthropy and firm value and LeClair and Gordon (2000) and Zhang et al. (2010) find a positive relationship between philanthropy and return on assets. However, Brown et al. (2006) find a positive (but economically insignificant) relationship between charitable giving and income.

Extant research uses contemporaneous links between corporate philanthropy and financial performance (LeClair 
\& Gordon, 2000; Seifert et al., 2004; Brown et al., 2006; Chen et al., 2008; Zhang et al., 2010). Some studies use a lead/lag relationship (Wang \& Qian 2011; Lev et al., 2010) to find a positive relationship between charitable giving and future revenue growth. Others also document a positive relationship between corporate socially responsible behavior and prior financial performance (McGuire et al., 1988; Waddock and Graves, 1997). Hillman and Keim (2001), using a broader measure of corporate social performance, identify corporate social activities that enhance stakeholder value from those that do not.

There are few papers that examine the links between international giving and future financial performance for service firms. Here, we examine the link between current giving by a sample of U.S. service firms and future financial performance using data over the 2004-2010 period. We add to the literature by isolating firms that give internationally and focusing exclusively on future performance. Although the direction of causality-the issue of whether current corporate giving influences future financial performance or vice versa-has been debated in the literature (Lev et al., 2010; Su \& He, 2010), this issue cannot be researched in this paper since only information on the incidence of foreign giving is available from the KLD database.

\section{Method}

\subsection{Hypotheses}

Based on theoretical discussions presented in section 2, testable hypotheses for each sample of firms (those that only give internationally (or both internationally and domestically)) and those that only give domestically, are developed. Two competing theories (the value enhancing theories and the agency cost theory) explain the relationship between charitable giving and future financial performance. However, whereas the value enhancing theories predict a positive relationship, the agency cost theory predicts a negative relationship. Hence, each null hypothesis is framed as one of "no relationship" between the variables of interest. Rejection of the null will provide support for competing theories based on the sign of the observed links.

H1(H2): No relationship exists between the incidence of giving and subsequent returns on assets for service firms that only give internationally or those that give both domestically and internationally (domestically)

\subsection{Predictor Variable: Operationalization of Construct}

The study is conducted using a sample of US service firms making foreign ownership acquisitions in foreign countries over the 2004-2010 period using data extracted from the publicly available US M\&A database. Brief descriptions of the data and data sources are presented in Table 1. Only cases where firms acquire ownership interests in foreign countries are included because ownership interests create a higher tendency towards foreign giving.

The dependent variable is FGIV, which assumes a value of 1 if US firms give a substantial portion (at least 20\%) of total contributions internationally (or internationally and domestically), and 0 if do not give at all. FGIV is measured in the same year as the acquisition year. The indicator variable, "Non-US Charitable Giving" to identify corporations that give outside the United States, is used. Similarly, DGIV captures firms who invest abroad, but only give domestically.

\subsection{Independent Variables: Control}

This section describes the list of independent control variables used in this study. These control variables have been identified as important determinants of corporate charitable giving in the literature (Cowan et al., 2013). Although the Cowan et al. (2013) paper deals with the determinants of international giving for US manufacturing firms, this study is used to motivate international variables for the service paper because of a paucity of studies linking international giving to future performance for service firms. Hence, support for the inclusion of the internationally oriented control variables are primarily derived from this paper. Since the control variables are different for foreign giving (foreign and domestic giving) and domestic giving, the segment to which the particular control variables are applicable are specified in brackets below.

First, SIZE of the firm is introduced as an important control variable. To capture SIZE, LTA (log of assets of the parent) and LEMP (log of total employees of the parent), are used. Both SIZE variables are measured in the year prior to the acquisition year (FGIV, DGIV). Second, RND, the ratio of research and development expense to total sales of the parent in the year prior to the acquisition year, is designed to capture the research and development intensity of the parent (FGIV, DGIV). Third, pre entry firm profitability is captured by the firm's return on assets, ROA, over the year preceding the acquisition year. If an agency-theoretic explanation is correct, then ROA would be expected to be negatively associated with giving. Alternatively, if giving represents a stimulus for value enhancement, ROA would be positively associated with giving (FGIV, DGIV). Fourth, the degree of cultural distance between the host country and the US is proxied using the well-known Hofstede (1980) 
measure (CD). Here, it is conjectured that foreign giving will positively influence financial performance in developing countries (FGIV only). FSPER is measured as the ratio of foreign sales to total sales for the firm in the year preceding the acquisition year, and is included to account for the level of international experience of the investing firm (FGIV only). Musteen, Dutta and Hermann (2009) use this proxy to capture the level of international business experience in their study involving foreign acquisitions.

As discussed earlier, agency theory posits a negative relationship between current giving and future financial performance (Jensen, 1986; Brown et al., 2006). Based on the existing literature, the ratio of total debt to book value in the year preceding the year of acquisition, DARATIO, is introduced as a monitoring variable (Zhang et al. 2010) (FGIV, DGIV). Prior literature suggests the use of the ratio of market value to book value or a simplified form of Tobin's Q measured in the year prior to acquisition (PBRATIO), as a measure of slack resources (Brown et al., 2006) (FGIV, DGIV. Next, free cash flow (FCFRATIO) in the year preceding the acquisition is introduced as a proxy for common slack resources (Seifert et al., 2003) (FGIV, DGIV). Finally, acquisitions in developing/developed countries are captured by ECDEV ( 1 for developing countries and 0 for developed countries) (FGIV only).

\subsection{Independent Variable of Interest}

FUTPERF is introduced as the variable subject to investigation. FUTPERF measures the surprise return on assets of the firm in the year subsequent to the year of foreign giving. Unlike other studies in the area, the impact of current giving in measured on earnings performance surprises. $\mathrm{ROA}_{\mathrm{t}+1}$ is initially regressed against $\mathrm{ROA}_{\mathrm{t}}$. The residuals from this OLS regression are designated as the earnings surprise:

$$
R O A_{t+1}=\alpha+\beta R O A_{t}+\varepsilon_{t}
$$

"Surprise" earnings are computed as FPERFSURP $=\operatorname{ROA}_{t+1}-\left[\alpha+\beta \mathrm{ROA}_{\mathrm{t}}\right]$ and are used in the second stage logit regression.

\subsection{Methodology}

Following prior literature, logit analysis is used since the dependent variable is a $0-1$ variable ( 1 if firms give internationally or both internationally and domestically, and 0 otherwise). Logit analysis determines the probability (p) of foreign (domestic) giving as a function of a set of independent variables. A positive sign for the coefficient implies that the variable increases the likelihood of foreign giving. The probability that the firm will give internationally given the independent variables $x_{1}, x_{2}, \ldots, x_{n}$ is

$$
\pi\left(x_{i}\right)=p\left(y=1 \mid x_{i}\right)=\frac{1}{1+e^{-\left(\alpha+\beta x_{i}\right)}}
$$

where $\mathrm{y}$ is the dependent variable, $\mathrm{x}_{\mathrm{i}}$ is the vector of independent variables (outlined in the previous section) for the $\mathrm{i}^{\text {th }}$ observation, $\alpha$ is the intercept parameter, and $\beta$ is the vector of regression coefficients (Altman and Brenner, 1981). The logistic regression model can be linearized as follows:

$$
y=\alpha+\beta_{1} x_{1}+\beta_{2} x_{2}+\cdots+\beta_{n} x_{n}+\varepsilon_{i}
$$

where:

$y$ : a dummy that captures whether the firm will give internationally $($ no $=0$, yes $=1$ )

$x_{i}$ : the list of independent variables; $\alpha=$ intercept and $\beta_{i}=$ regression coefficients on $x_{i}$

\section{Results}

The SAS LOGIST procedure is used for estimation of logit regression model parameters (Harrell 1986). In Table 1 , sample descriptive characteristics for the foreign (henceforth, reference to the foreign sample also includes the foreign/domestic sample) and domestic samples are presented. 
Table 1. Summary sample characteristics: sample US service firms

\begin{tabular}{llllllll}
\hline \multicolumn{2}{l}{ FOREIGN \& FOREIGN/DOMESTIC GIVING } & \multicolumn{7}{l}{ DOMESTIC GIVING } \\
\hline VARIABLE & $\mathbf{N}$ & MEAN & STD DEV & VARIABLE & N & MEAN & STD DEV. \\
\hline FGIV & 575 & 0.07826 & 0.26882 & DGIV & 659 & 0.19575 & 0.39708 \\
DARATIO & 553 & 14.58917 & 16.92844 & DARATIO & 635 & 15.30903 & 16.78407 \\
PBRATIO & 555 & 3.86067 & 13.64189 & PBRATIO & 639 & 3.94720 & 12.76632 \\
CD & 575 & 1.49164 & 1.33933 & FCFRATIO & 635 & 0.06931 & 0.11390 \\
ECDEV & 575 & 0.24174 & 0.42851 & ROA & 641 & 0.06698 & 0.11261 \\
FCFRATIO & 551 & 0.07296 & 0.11354 & FUTPERF & 613 & 0.05942 & 0.13377 \\
ROA & 557 & 0.06357 & 0.12023 & RND & 655 & 0.07525 & 0.09208 \\
FUTPERF & 536 & 0.05366 & 0.14273 & LTA (LOGS) & 641 & 21.80476 & 1.85250 \\
FSPER & 467 & 0.38177 & 0.19535 & LEMP (LOGS) & 652 & 9.12641 & 1.99221 \\
RND & 571 & 0.07650 & 0.09363 & & & & \\
LTA (LOGS) & 557 & 21.54112 & 1.79335 & & & & \\
LEMP (LOGS) & 570 & 8.85089 & 1.85989 & & & \\
No. of Firms:45 & & & & No. of Firms: 49 & & \\
\hline
\end{tabular}

\section{Data Descriptions:}

LEMP is the actual number of employees in the year prior to the year of foreign/domestic giving, expressed in natural logarithms;

ROA is the pre entry firm profitability measured as ROA in the year prior to the year of acquisition;

RND is the ratio of parent's research and development expenses expressed as a function of total sales in the year prior to the year of acquisition of the entity. RND is expressed as a percentage. Missing RND values are replaced by a zero (see Lev et al., 2010);

FSPER is the ratio of foreign sales to total sales measured in the year prior to the year of acquisition;

$\mathrm{CD}$ is a composite index showing the overall cultural distance of each host country from the parent country (the United States) using Hofstede's four indices (Hofstede, 1980; Hofstede \& Bond, 1988);

LTA is the dollar total assets of the parent in the year prior to the acquisition year of the foreign entity, expressed in natural logarithms;

DARATIO is the ratio of long term debt to total assets in the year prior to the acquisition year;

FCFRATIO is the free cash flow in the year prior to the acquisition year.

PBRATIO is the ratio of market to book ratio of the common stock of the firm in the year prior to the acquisition year.

FGIV is a dummy that assumes a value of 1 if the US firm gives internationally (or internationally and domestically), and 0 if it does not give at all;

ECDEV is a dummy that assumes a value of 1 if the US service firm investment is in a developing country and 0 if the investment is in a developed country;

FUTPERF is return on assets for the firm at time $t+1$, one year after the firm gives internationally;

DGIV is a dummy that assumes a value of 1 if the US firm gives domestically and 0 if it does not give at all.

Data Sources: Giving data is obtained from the KLD data base. The remaining data is obtained as follows: For all variables (exceptions noted below), US M\&A database (Datastream, ZEPHYR). ECDEV is calculated by the authors. CD is computed from the tables provided in Kogut and Singh (1988). Since the computation procedures are well known in the IB literature, the procedures are not reproduced here.

Please note that these profiles reflect the raw data, and not the final sample used in subsequent logit regressions.

\subsection{Foreign Giving (or Foreign and Domestic Giving) Sample}

The foreign giving sample contains 43 cases of foreign giving and 489 cases where US service firms do not give at all. The sample assets (in millions of dollars) range from $\$ 41.50$ million to $\$ 1.175$ billion. Number of employees range from a minimum of 45 employees to a maximum of over 1.5 million employees. The sample reflects diversion in terms of countries and industries. Countries where US service firms have made acquisitions include UAE (4), Argentina (6), Austria (11). Belgium (8), Bulgaria (1), Brazil (13), Canada (76), Switzerland 
(6), Chile (4), China (34), Czech Republic (5), Germany (50), Ecuador (1), Egypt (1), Spain (11), Finland (7), France (47), Great Britain (113), Hong Kong (6), Hungary (3), Iceland (1), Israel (21), India (33), Italy (4), Jordan (1), Japan (8), South Korea (11), Luxembourg (2), Mexico (3), Netherlands (24), Norway (2), Philippines (1), Poland (3), Portugal (3), Romania (3), Russia (12), Slovenia (1), Sweden (16), Singapore (6), Thailand (3), Turkey (1), Taiwan (4), Uruguay (1), Venezuela (1) and South Africa (3). The final total reflects cases from 45 countries and capture both developed and developing countries. The sample also includes 15 (16 for the domestic) different 2-digit SIC industries. These include (SIC code, Industry name, (foreign sample, domestic sample): 53-Merchandise Stores (0,1); 54-Food Stores (8, 20); 55-Auto dealers/service stations $(4,4)$; 56-Apparel/Accessory Stores (7,7); 57-Furniture Stores $(4,11) ; 58$-Eating/drinking stores $(5,5) ; 59$-Miss. Retail $(8,14)$; 70-Hotels $(8,10) ; 72$-Personal Services $(4,4)$; 73-Business Services $(392,450)$; 75-Auto Repair Services (2,2);78-Miss. Repair (14,15); 79-Amusement Recreational (17,17); 80-Health Services (1,1); 82-Educational Services $(4,4)$ 87-Engineering Management Services $(97,94)$. In total, there are 575 (659) cases for the foreign (domestic) sample.

The correlation tables for both samples (not reported here, but available on request from the authors) suggest that FGIV is highly correlated with sample explanatory control variables. In turn, many of the independent variables are also significantly correlated with each other. For instance, LTA (log of total assets) is (as expected) highly correlated with LEMP (log of total employees). Similarly, ROA (return on assets) is also highly correlated with RND (ratio of research and development expenses to total sales) and LEMP. DARATIO, CD and ECDEV are also highly correlated with many independent variables. However, only the correlation between LTA/LEMP seem strong enough (coefficient of 0.783 ) to create multicollinearity problems. These conclusions are confirmed by the variance inflation factors (VIFs) presented in Table 2. Hence, factor analysis involving LEMP and LTA was used to extract a common (SIZE) factor for subsequent analysis (both subsamples). Table 2 reflects use of factor scores for the foreign sample. Finally, tests confirm that continuous independent sample variables do not violate the normality assumption. (Results of these runs are available on request from the authors).

Table 2. Foreign giving/foreign domestic giving and future firm performance US service firms (stepwise regression results only)

\begin{tabular}{lllllll}
\hline & STD. & \multicolumn{3}{c}{ WALD } & VARIANCE \\
\hline VAR & DF & ESTIMATE & ERROR & CHI-SQUARE & PR $>$ CHISQ & INF. FACTOR $^{\mathrm{a}}$ \\
\hline INTERCEPT & 1 & -26.5293 & 7.9059 & 11.2604 & $0.0008^{* * *}$ & - \\
CD & 1 & -0.8608 & 0.5005 & 2.9586 & $0.0854^{*}$ & 1.0676 \\
FSPER & 1 & 8.9012 & 4.7883 & 3.4557 & $0.0630^{*}$ & 1.1170 \\
SIZE $^{\mathrm{b}}$ & 1 & 11.4388 & 3.1860 & 12.8906 & $0.0003^{* * *}$ & 1.1940 \\
ROA & 1 & 29.9343 & 16.2085 & 3.4107 & $0.0648^{*}$ & 2.5325 \\
RND & 1 & 100.4 & 30.5055 & 10.8295 & $0.0010^{* * *}$ & 1.3743 \\
FCFRATIO & 1 & 33.7267 & 16.0938 & 4.3917 & $0.0361^{* *}$ & 2.4951 \\
BUSSERV & 1 & -12.6161 & 4.1875 & 9.0772 & $0.0026^{* * *}$ & 1.3378 \\
\hline presents significance at the $1 \%$ (respectively $5 \%, 10 \%)$ levels. & &
\end{tabular}

Note. ${ }^{* * *(* *, *)}$ represents significance at the $1 \%$ (respectively $5 \%, 10 \%$ ) levels.

${ }^{a}$ The Variance Inflation Factors were generated using the PROC REG procedure in SAS.

${ }^{\mathrm{b}}$ SIZE represents factor scores developed from LEMP and LTA, and captures the size of the firm.

BUSSERV is a dummy that captures the business service industry (2 digit SIC code 73 ), since $68.17 \%$ of the foreign sample is comprised of firms in this industry.

Dependent Variable: Foreign Giving (FGIV). FGIV $=1$ if the firm gives internationally (or both internationally and domestically), and zero if they do not give at all.

$\mathrm{N}=458$; CASES WHERE FIRMS ONLY GIVE INTERNATIONALLY OR BOTH INTERNATIONALLY AND DOMESTICALLY $=43$; CASES WHERE FIRMS DO NOT AT ALL $=385$; OVERALL CHI-SQ = 249.02, 7 DF, $\mathrm{p}<.0001$

Legend: Variable definitions are presented in Table 1.

Strong correlations between many of the independent variables warrant the use of the stepwise regression methodology. Results reported in Table 2 for the foreign sample indicate that the regressions have significant overall explanatory power with model chi squares of $249.02(\mathrm{p}<.0001)$. In addition, FPERFSURP is found not 
to be significant. In addition, many of the independent control variables are also significant. For instance, SIZE $(<1 \%)$, FSPER $(10 \%)$, ROA $(10 \%)$, RND $(<1 \%)$, FCFRATIO $(5 \%)$ were found to be positively associated with firm level foreign giving. CD $(10 \%)$ and BUSSERV $(<1 \%)$ were found negatively associated with firm level foreign giving. The findings of a negative and significant relationship between firms in the Business Service industry and foreign giving is an interesting result and suggest that industry firms tend not to give internationally relative to other firms in the sample. The giving properties of this group are investigated in a separate section.

Overall, the results as presented in Table 2 do not reject Hypotheses 1. It appears that US service firms do not receive any future financial benefits when they only give internationally (or internationally/domestically), after controlling for other factors found important in the literature.

\subsection{Domestic Giving Only}

The final domestic giving sample contains 119 cases of firms giving domestically, with 472 cases where US firms do not give at all. The sample assets and number of employees are quite similar to the foreign giving sample. The sample industry diversity is also similar to the foreign giving sample diversity (these breakdowns have been presented earlier). The correlation table results also mirror results reported for the foreign sample. As before, the LTA/LEMP correlation (coefficient $=0.815$ ), is used to capture the SIZE factor. Stepwise regressions results reported in Table 3 suggest that the logit regressions have significant overall explanatory power with model chi squares of $295.48(\mathrm{p}<.0001)$. A key finding is that the variable of interest (FPERFSURP) is found significant $(<1 \%)$. In addition, and as expected, many independent control variables are found significant: SIZE $(<1 \%)$, ROA $(<1 \%)$, and RND $(1 \%)$ were found to be positively associated with firm level domestic giving. The results as presented in Table 3 reject Hypotheses 2 in favor of the value enhancing theories and against agency theory. It appears that service firms do receive significant future financial benefits when they only give domestically, but not when they give internationally. These results are consistent with those reported in Lev et al. (2010).

Dependent Variable: Domestic Giving (DGIV). DGIV $=1$ if the firm gives domestically, zero if they do not give at all.

Table 3. Domestic giving and future firm performance: US service firms (Stepwise regression results only)

\begin{tabular}{lllllll}
\hline & STD & \multicolumn{3}{c}{ WALD } & VARIANCE \\
\hline VAR & DF & ESTIMATE & ERROR & CHI-SQUARE & PR $>$ CHISQ & INF. FACTOR $^{\mathrm{a}}$ \\
\hline INTERCEPT & 1 & -5.4861 & 0.4984 & 121.1770 & $<.0001^{* * *}$ & - \\
SIZE $^{\text {B }}$ & 1 & 2.9836 & 0.2934 & 103.4118 & $<.0001^{* * *}$ & 1.0746 \\
ROA & 1 & 12.0751 & 2.0957 & 33.1999 & $<.0001^{* * *}$ & 1.0478 \\
RND & 1 & 14.6349 & 2.0451 & 51.2090 & $<.0001^{* * *}$ & 1.0502 \\
FPERFSURPC & 1 & 8.3597 & 3.0233 & 7.6456 & $0.0057^{* * *}$ & 1.0105 \\
\hline
\end{tabular}

Note. ${ }^{* * *(* *,)}$ represents significance at the $1 \%$ (respectively, $5 \%, 10 \%$ ) levels.

${ }^{\text {a }}$ The Variance Inflation Factors were generated using the PROC REG procedure in SAS

${ }^{\mathrm{b}}$ SIZE represents factor scores developed from LEMP and LTA and accounts for size of the firm.

${ }^{c}$ FPERFSURP captures residuals obtained by regressing the future performance variable (ROA one year later) on current ROA. Hence it captures the 'surprise' component of the return on assets. BUSSERV is a dummy that captures the business service industry (2 digit SIC code 73 ), since $68.28 \%$ of the domestic sample is comprised of firms in this industry.

$\mathrm{N}=591$; CASES WHERE FIRMS ONLY GIVE DOMESTICALLY $=119$; CASES WHERE FIRMS DO NOT GIVE AT ALL $=472$; OVERALL CHI-SQ $=295.48,4$ DF, $\mathrm{p}<.0001$

Legend: Variable definitions are presented in Table 1.

\subsection{Business Services Group Subsection Results}

In the previous section, it was reported that for the business service segment (SIC code 73), FGIV was significantly negatively related to foreign giving. Besides, this industry captures over $68 \%$ of sample observations. Is the current giving/FPERSURP relationship for both subsamples influenced by membership in the business service industry? Do variables found significant earlier continue to remain significant for the business service subsample? Regressions were run separately for each group. Unfortunately, for the foreign group, there were too few firms that gave internationally to establish convergence of the regression results. For 
the domestic group, remarkably, all variables continued to retain significance in the business service subsample. In addition, DARATIO was also found significant for this subgroup. (Complete regression results are available on request from the authors).

\section{Policy Implications, Limitations, and Conclusions}

First, the empirical findings confirm the following. The incidence of current foreign giving (or foreign/domestic giving) is positively related to future firm financial performance for the sample of domestic givers only, but not for the sample of foreign/foreign-domestic givers. It seems that firms who operate globally only receive altruistic benefits from giving. Domestic givers also receive financial benefits. The domestic givers may have mastered the art of strategic giving better than foreign givers. Further research may allow us to understand this process better.

There are several limitations of this study. First, the KLD database used only captures the incidence of giving and does not report giving by country or dollars. Further research that includes this information would enrich the study. Finally, firms may want to consider issues such as, what strategic decisions need to be made at the individual firm level to maximize returns from giving dollars? Finally, firms in countries other than the US may also be explored in terms of the current foreign giving/future financial performance relationship.

\section{References}

Altman, E. I., \& Brenner, M. (1981). Information effects and stock market response to signs of firm deterioration. Journal of Finance and Quantitative Analysis, (16), 35-51. http://dx.doi.org/10.2307/2330665

Brammer, S., \& Millington, A. (2003). The effect of stakeholder preferences, organizational structure and industry type on corporate community involvement. Journal of Business Ethics, 45(3), 213-226. http://dx.doi.org/10.1023/A:1024151528646

Brammer, S., \& Millington, A. (2005). Corporate reputation and philanthropy: An empirical analysis. Journal of Business Ethics, 61(1), 29-44. http://dx.doi.org/10.1007/s10551-005-7443-4

Brown, W. O., Helland, E., \& Smith, J. K. (2006). Corporate philanthropic practices. Journal of Corporate Finance, 12(5), 855-877. http://dx.doi.org/10.1016/j.jcorpfin.2006.02.001

Chen, J., Patten, D., \& Roberts, R. (2008). Corporate charitable contributions: A corporate social performance or legitimacy strategy? Journal of Business Ethics, 82(1), 131-144. http://dx.doi.org/10.1007/s10551-007-9567-1

Committee Encouraging Corporate Philanthropy. (2012). Giving in numbers. Retrieved from http://www.corporatephilanthropy.org/research/benchmarking-reports/giving-in-numbers.

Cowan, A., Padmanabhan, P., Huang, C., \& Wang, C. (2013). The determinants of foreign giving: An exploratory empirical investigation of US manufacturing firms. International Business Review, 22, 407-420. http://dx.doi.org/10.1016/j.ibusrev.2012.05.005

Dowling, J., \& Pfeffer, J. (1975). Organizational legitimacy: social values and organizational behavior. Pacific Sociological Review, 18(1), 122-136.

Fama, E. F. (1980). Agency problems and the theory of the firm. Journal of Political Economy, 88(2), 288-307.

Fama, E. F., \& Jensen, M. N. (1983). Separation of ownership and control. Journal of Law and Economics, 26.

Harrell, F. Jr. (1986). The LOGIT procedure. In R. P. Hastings (Ed.), SUGI Supplemental Library User's Guide (5th ed.). SAS Institute, Cary, NC.

Hillman, A., \& Keim, G. (2001). Shareholder value, stakeholder management, and social issues: What's the bottom line? Strategic Management Journal, 22(2), 125-139.

Hofstede, G. (1980). Culture's consequences. Sage, Beverly Hills, CA.

Hofstede, G., \& Bond, M. (1988). The Confucius connection: From cultural roots to economic growth. Organizational Dynamics, 4-21. http://dx.doi.org/10.1016/0090-2616(88)90009-5

Jensen, M., \& Meckling, W. (1976). Theory of the firm: Managerial behavior, agency costs and ownership structure. Journal of Financial Economics, 3(4), 305-360. http://dx.doi.org/ 10.1007/978-94-009-9257-3_8

Jensen, M. (1986). Agency costs of free cash flow, corporate finance, and takeovers. American Economic Review, 76(2), 323-329. http://dx.doi.org/10.2139/ssrn.99580 
Kogut, B., \& Singh, H. (1988). The effect of national culture on the choice of entry mode. Journal of International Business Studies, 19(3), 411-432. http://dx.doi.org/10.1057/palgrave.jibs.8490394

LeClair, M. S., \& Gordon, K. (2000). Corporate support for artistic and cultural activities: What determines the distribution of corporate giving? Journal of Cultural Economics, 24, 225-241. http://dx.doi.org/10.1023/A:1007686500896

Lev, B., Petrovits, C., \& Radhakrishnan, S. (2010). Is doing good for you? How corporate charitable contributions enhance revenue growth. Strategic Management Journal, 31(2), 182-200. http://dx.doi.org/10.1002/smj.810

Margolis, J. D., Elfenbein, H. A., \& Walsh, J. P. (2007). Does it pay to be good? A meta-analysis and redirection of research on the relationship between corporate social and financial performance. Retrieved from http://papers.ssrn.com/sol3/papers.cfm?abstract_id=1866371

Maron, I. Y. (2006). Toward a unified theory of the CSP-CFP link. Journal of Business Ethics, 67(2), 191-200. http://dx.doi.org/10.1007/s10551-006-9023-7

McGuire, J. B., Sundgren, A., \& Schneeweis, T. (1988). Corporate social responsibility and firm financial performance. Academy of Management Journal, 31(4), 854-872. http://dx.doi.org/10.2307/256342

Muller, A., \& Whiteman, G. (2009). Exploring the geography of corporate philanthropic disaster response: A study of fortune global 500 firms. Journal of Business Ethics, 84(4), 589-603. http://dx.doi.org/10.1007/s10551-008-9710-7

Musteen, M., Datta, D., \& Hermann, P. (2009). Ownership structure and CEO compensation: Implications for the choice of foreign market entry modes. Journal of International Business Studies, 40, 321-338. http://dx.doi.org/10.1057/jibs.2008.63

Navarro, P. (1988). The income elasticity of corporate contributions. Quarterly Review of Economics and Business, 28(4), 66-75.

Porter, M. E., \& Kramer, M. R. (2002). The competitive advantage of corporate philanthropy. Harvard Business Review, 80, 56-68.

Roberts, P. W., \& Dowling, G. R. (2002). Corporate reputation and sustained superior financial performance. Strategic Management Journal, 23, 1077-1093. http://dx.doi.org/10.1002/smj.274

Saiia, D. H., Carroll, A. B., \& Buchholtz, A. K. (2003). Philanthropy as strategy when corporate charity "Begins at Home". Business \& Society, 42(2), 169-201. http://dx.doi.org/10.1177/0007650303042002002

Sanchez, C. M. (2000). Motives for corporate philanthropy in El Salvador: Altruism and political legitimacy. Journal of Business Ethics, 27(4), 363-375. http://dx.doi.org/ 10.1023/A:1006169005234

Seifert, B., Morris, S. A., \& Bartkus, B. R. (2003). Comparing big givers and small givers: Financial correlates of corporate philanthropy. Journal of Business Ethics, 45(3), 195-211. http://dx.doi.org/10.1023/A:1024199411807

Seifert, B., Morris, S. A., \& Bartkus, B. R. (2004). Having, giving, and getting: Slack resources, corporate philanthropy, and firm financial performance. Business and Society, 43(2), 135-161. http://dx.doi.org/10.1177/0007650304263919

Shocker, A. D., \& Sethi, S. P. (1974). An approach to incorporating social preferences in developing corporate action strategies. In S. P. Sethi (Ed.), The Unstable Ground: Corporate Social Policy in a Dynamic Society. Melville Publishing, Los Angeles, CA.

Strike, V. M., Gao, J., \& Bansal, P. (2006). Being good while being bad: social responsibility and the international diversification of US firms. Journal of International Business Studies, 37, 850-862. http://dx.doi.org/10.1057/palgrave.jibs. 8400226

$\mathrm{Su}, \mathrm{J} .$, \& He, J. (2010). Does giving lead to getting? Evidence from Chinese private enterprises. Journal of Business Ethics, 93(1), 73-90. http://dx.doi.org/10.1007/s10551-009-0183-0

Turban, D. B., \& Greening, D. W. (1996). Corporate social performance and organizational attractiveness to prospective employees. Academy of Management Journal, 40, 658-672. http://dx.doi.org/10.2307/257057

Waddock, S. A., \& Graves, S. B. (1997). The corporation social performance-financial performance link. $\begin{array}{llll}\text { Strategic Management 303-319. } & \text { Journal, }\end{array}$ http://dx.doi.org/10.1002/(SICI)1097-0266(199704)18:4<303::AID-SMJ869>3.0.CO;2-G 
Waddock, S., \& Smith, N. (2000). Relationships: The real challenge of corporate global citizenship. Business and Society Review, 105(1), 47-62. http://dx.doi.org/10.1111/0045-3609.00064

Wang, H., Choi, J., \& Li, J. (2008). Too little or too much? Untangling the relationship between corporate philanthropy and firm financial performance. Organization Science, 19(1), 143-159. http://dx.doi.org/10.1287/orsc.1070.0271

Wang, H., \& Qian, C. (2011). Corporate philanthropy and corporate financial performance: The roles of stakeholder response and political access. Academy of Management Journal, 54(6), 1159-1181. http://dx.doi.org/10.5465/amj.2009.0548

Wilson, R. (1985). Reputation in games and markets. In A. E. Roth (Ed.), Game-theoretic models of bargaining. Cambridge University Press, Cambridge, MA.

United States CIA. (2013). World Fact-book. Retrieved from https://www.cia.gov/library/publications/the-world-factbook/geos/us.html

Zhang, R., Zhu, J., Yue, H., \& Zhu, C. (2010). Corporate philanthropic giving, advertising intensity, and industry competition level. Journal of Business Ethics, 94(1), 39-52. http://dx.doi.org/10.1007/s10551-009-0248-0

\section{Copyrights}

Copyright for this article is retained by the author(s), with first publication rights granted to the journal.

This is an open-access article distributed under the terms and conditions of the Creative Commons Attribution license (http://creativecommons.org/licenses/by/3.0/). 